\title{
NOTES ON THE PATHOLOGY OF YELLOW FEVER IN GUINEA-PIGS. ${ }^{1}$
}

\author{
By Harald Seideunv, M.D., Scientific Secretary, Yellow Fever Bureau, \\ School of Tropical Medicine, University of Liverpool.
}

\section{(Plates XXIV.-XXV.)}

VARIoUs authors have succeeded in transmitting yellow fever to guinea-pigs. The writer has experimented on about 150 animals, in conjunction with Dr. Diego Hernandez, Dr. Andrew Connal, Professor Ernest Glynn, or alone. Post-mortem examinations have been made in the majority of these cases, but histological examinations of the organs so far in twenty cases only, in which two or more organs bave been embedded and stained in various ways. Some information has also been obtained by the examination of impression preparations from the various organs. In this communication spleen and liver are the organs chiefly dealt with.

The most common anatomical lesions observed on macroscopical examination are hyperæmia, ecchymoses, and erosions in the gastric mucosa, and congestion of the lungs. The liver is sometimes hyperæmic, sometimes on the contrary pale, and it may be slightly yellowish or showing yellow patches. The gall-bladder is sometimes considerably distended. The bile appears normal in colour and consistency; at any rate, the consistency has not been increased. The spleen appears normal on naked-eye examination. The kidneys are often congested, and sometimes show minute hæmorrhages, also, occasionally, small yellowish patches. Petechiæ have in a few cases been observed on the peritoneum and pleuræ. Jaundice has not been observed. In one case a hæmatoma of the tunica albuginea and necrosis of the testicle were seen.

Microscopical examination of the lungs shows hyperæmia with the usual hæmorrhages into the alveoli, and accompanied by more or less marked desquamation of the epithelium, and sometimes by slight inflammatory infiltration.

${ }^{1}$ [Received July 11, 1914.] Communicated to the Pathological Society of Grcat Britain and Ireland, June 26-27, 1914. 
Sections through a gastric petechia show dilatation of the vessels and capillaries, infiltrating hæmorrhages in the mucosa and submucosa, and slight inflammatory infiltration and exudation (Plate XXIV. Fig. 1).

Sections of the liver show patches of hyperæmia and, occasionally, infiltrating hæmorrhages. There is often marked cellular degeneration, the normal reticular structure of the protoplasm having disappeared in certain groups of cells, whilst it is preserved in other cells in the same organ; the protoplasm often stains poorly, though the nuclei are well preserved. Many cells show vacuoles, either one large vacuole or several smaller ones. Some of the vacuoles contain fat, but in others the contents do not stain with sudan III. or scharlach $R$., or with nile-blue sulphate. The vacuolation is irregularly distributed throughout the lobuli, and often occurs together with hyperæmia (Plate XXV. Fig. 5), in which case a certain number of liver cells appear compressed. Necrobiotic phenomena are common, the protoplasm being more or less disintegrated, and the nuclei showing various stages of karyolysis or karyorrhexis. Other cells are seen which are reduced in size, with dense protoplasm and pyknotic nuclei. The necrobiotic cells occur either isolated or, more frequently, in patches. Isolated necrobiotic cells may occur amongst cells containing vacuoles, and larger groups are observed in the vicinity of hyperæmic areas, but their immediate surroundings are more often completely anæmic. In some places the necrosis is far advanced (Plate XXV. Fig. 6); in such foci there is commencing invasion of polymorpho-nuclear leucocytes, and occasionally the liver tissue has been almost completely displaced by groups of round cells (Plate XXV. Fig. 8). In one case a peculiar form of necrosis is observed, which appears to be of an acute type (Plate XXV. Fig. 7) ; the cells and their nuclei have preserved, approximately, their normal outlines and size, or the cells are enlarged, but the protoplasm is structureless and the nuclei stain poorly or not at all. Such foci are surrounded by necrobiotic cells of the ordinary types, especially by cells with pyknotic nuclei, and leucocytes have invaded their peripheral parts. The necrobiotic phenomena are irregularly distributed, but are most marked in the middle portions of the lobules. Mild inflammatory reaction is, in a few cases, seen not only in connection with the necrotic foci, but also in the periportal stroma. In one case multiple abscesses were seen. In some livers the endothelial cells of the capillaries (Kupffer's cells), and also some of the endothelial cells of the larger vessels, as well as free macrophages in their interior, contain pigment which gives an iron reaction; sometimes they contain fragments of erythrocytes. The liver cells very rarely contain pigment. The bile capillaries, when examined, have not been found distended.

The pancreas has only been examined in a few cases. The structure has, on the whole, been found normal, but small foci have been 
observed, consisting of necrobiotic and vacuolated cells (Plate XXIV. Fig. 2).

The kidneys show patches of hyperænia and sometimes interstitial hæmorrhages. Various stages of degenerative and necrobiotic changes of the epithelium are observed, especially in the convoluted tubules, which often contain granular masses and débris. Also the capsules of Bowman are occasionally seen to contain granular masses, the glomeruli being contracted (Plate XXIV. Fig. 3). The stroma has in several cases been found cedematous, especially that of the pyramids.

Microscopical examination of the spleen shows interesting phenomena, in spite of the normal size and colour of this organ. The amount of blood appears normal in the majority of cases, but in some it is unquestionably reduced, and in others it is considerably enlarged. Erythro-phagocytosis is often very marked, and there is always a more or less intense pigmentation (Plate XXIV. Fig. 4). Large, sometimes enormous, amounts of yellow pigment are contained in cells, apparently to a large extent endothelial cells, in the trabeculæ and reticulum of the pulp, but not in the Malpighian corpuscles; only in a few cases have pigment-containing cells been seen in the peripheral portions, and in two cases of excessive pigmentation even in small numbers in the interior, of the Malpighian corpuscles. The pigment is amorphous, of a bright yellow colour; the granules and globules often turn blue with potassium ferrocyanide and $\mathrm{HCl}$, but sometimes they only take on a somewhat greenish colour, and some granules remain yellow. The pigment-containing cells usually show a diffuse blue staining of their protoplasm, in which more intense blue, or green, or yellow particles are seen. Ope and the same phagocyte often contains erythrocytes, fragments of red cells, and pigment. Spleens were examined from animals which had been killed or had died at the end of periods varying from four days to about three months from the day of inoculation. The phenomena described were already marked in the earliest cases, increased in intensity for some weeks, and after five to six weeks appeared to decrease slightly. In one normal guinea-pig pigmentation was almost absent, in another it was very slight, and in an animal killed five days after an intraperitoneal injection of normal guinea-pig's blood it seemed hardly increased. Erythro-phagocytosis was very slight in these three cases. I need not further discuss the possibility that the pigmentation might be due to the injection of blood, as one of the most intense pigmentations was seen in a guineapig which had been infected, not by inoculation of blood, but by means of infected mosquitoes.

Various of the lesions here described may be of importance for a better understanding of the pathology of yellow fever. Thus the erythro-phagocytosis and destruction of hæmoglobin in the spleen, and to a slight extent in the liver, may assist us in explaining the 
jaundice, especially in view of recent investigations on toxic and hæmolytic jaundice by Sterling, M'Nee, Pearce, and others.

In yellow fever in the human subject, necrobiosis is probably the most important phenomenon observed in the liver. A midzonal necrosis has been described by da Rocha-Lima $\left(1912^{3}\right)$ as characteristic of yellow fever, but the observation cannot be accepted as final, as I have not found this type to be of constant occurrence, and on the other hand similar lesions have been described by Opie (1904 ${ }^{2}$ ), Ogata $\left(1913^{1}\right)$, and others in cases of septic icterus. It is, however, a very common type of necrosis, and, at any rate, necrobiotic phenomena are always observed in livers from yellow fever cases; it may well be that da Rocha-Lima is right in considering other phenomena -e.g., hyperæmia, hæmorrhages, and fatty change-as being of secondary importance. It is therefore of interest that the necrobiotic phenomena here described are most marked in the middle zones of the lobules, although on the whole they must be classified as focal rather than zonal.

The gastric, pancreatic, and renal lesions are similar to those observed in human cases, though less marked. For the sake of comparison it must be remembered that post-mortem changes are usually somewhat advanced in human material, whilst in my present experimental material they are either absent or very little marked.

\section{REFERENCES.}

1. OGata, T. . . . . . . "Ueber einen Fall von septischem Ikterus," Beitr. z. path. Anat. u. z. allg. Path., Jena, 1913, Bd. lv. SS. 315-321.

2. OpIE, E. L. . . . . . . "Zonal Necrosis of the Liver," Journ. Med. Research, Boston, Mass., 1904, vol, xii. pp. 147-167.

3. Rocha-Lima, H. תA . . . "Zur pathologischen Anatomie des Gelbfiebers," Verhandl. d. Deutsch. Pathol. Gesellsch., Jena, 1912, 15 Tagung, SS. 163182.

\section{DESCRIPTION OF PLATES XXIV.-XXV.}

\section{Plate XXIV.}

FiG. 1.-Stomach, showing capillary hyperæmia, infiltrating hæmorrhage, and commencing inflammatory infiltration. ( $x 380$.)

Fig. 2.-Pancreas, vacuolation and necrobiosis of cells. $(x 630$.

FIG. 3.-Ridney. Exudate in Bowman's capsule, glomerulus contracted ; degeneration of epithelia of convoluted tubules. $(x$ 380.)

FIG. 4. - Spleen. Intense pigmentation, showing the characteristic distribution. ( $\times 67$.)

PLATE XXV.

FIG. 5.-Liver. Hyperemia and vacnolation of cells. $(x 630$.

Fig, 6.-Liver. Focal necrosis. $(\times 630$. $)$

Fio. 7.-Liver. Another form of focal necrosis. ( $x \mathbf{3 8 0}$.)

Pig. 8.-Liver. Microcellular infiltration. $(x$ 380.) 


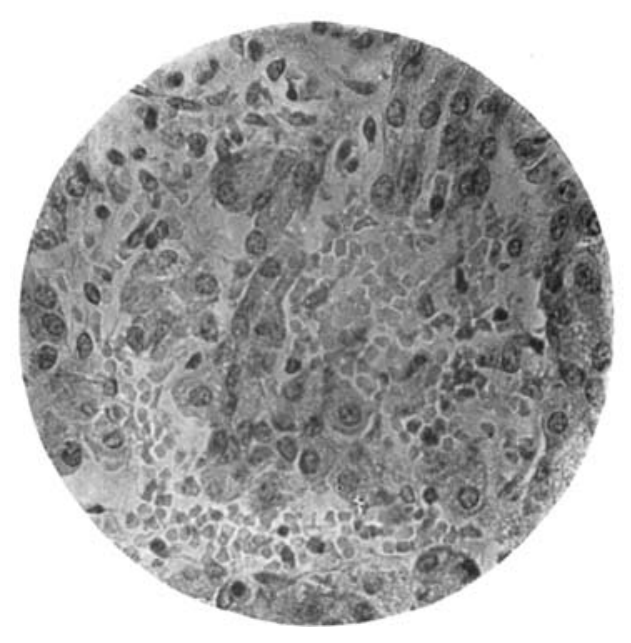

Fic. 1.

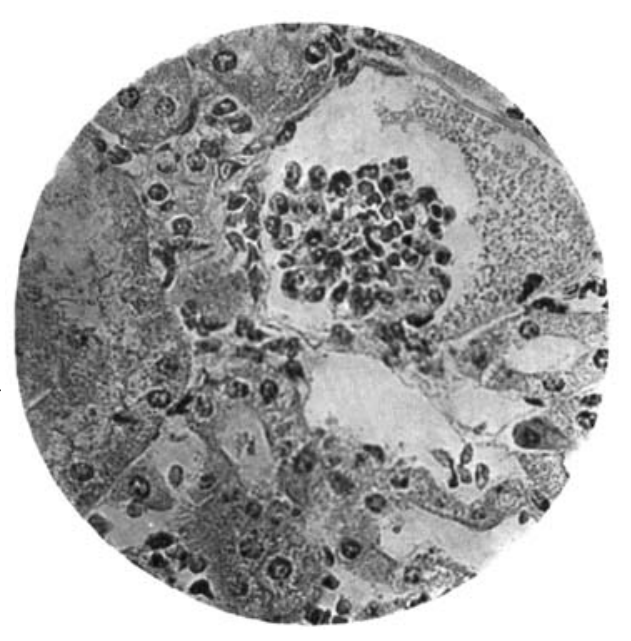

Fra. 3.

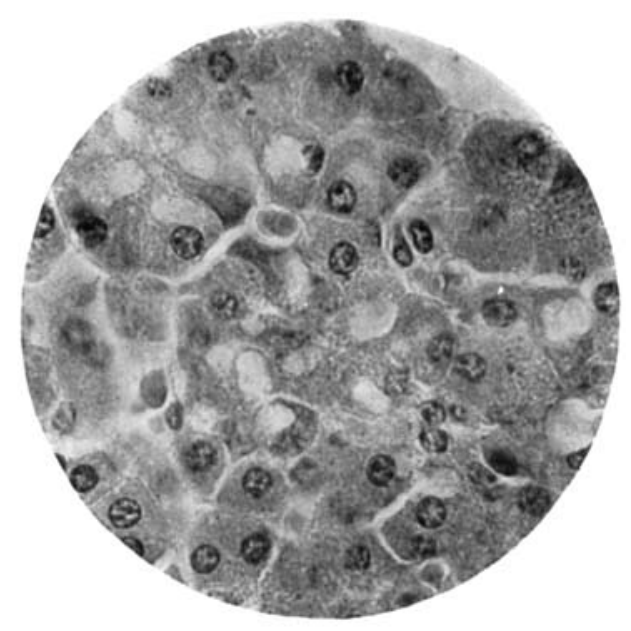

Fro. 2.

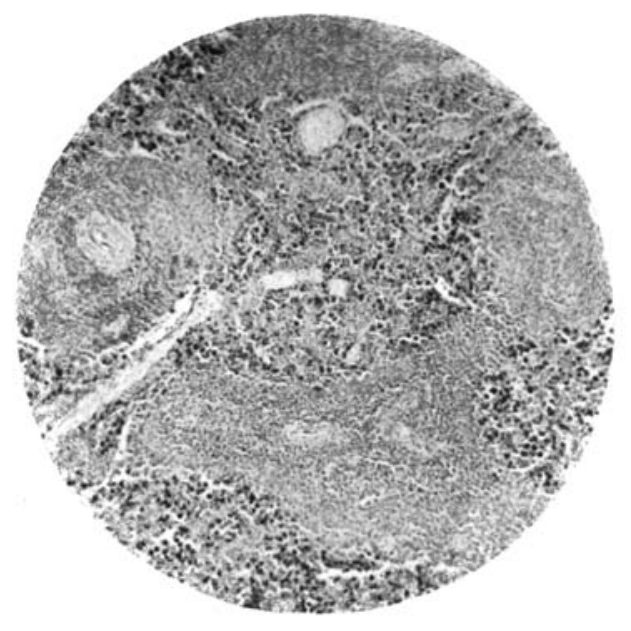

FIo. 4. 


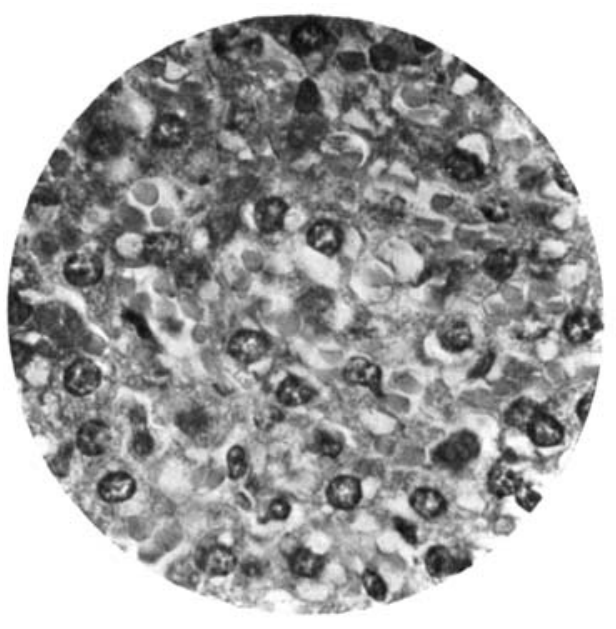

Fia. 5.

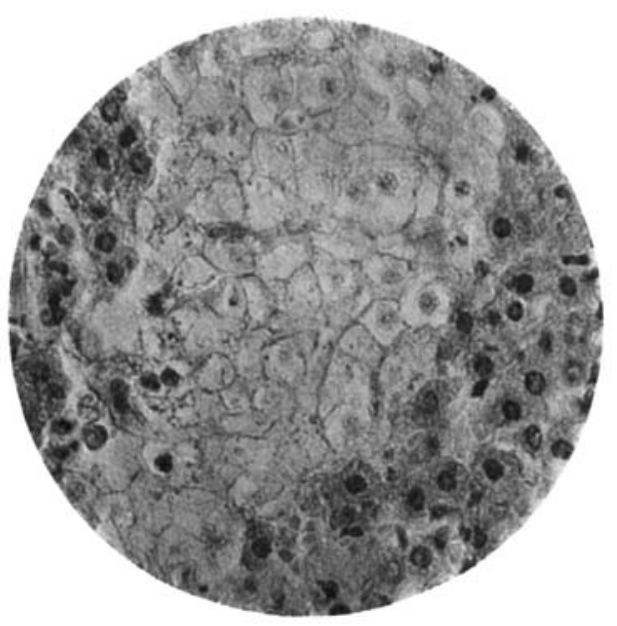

F19. 7 .

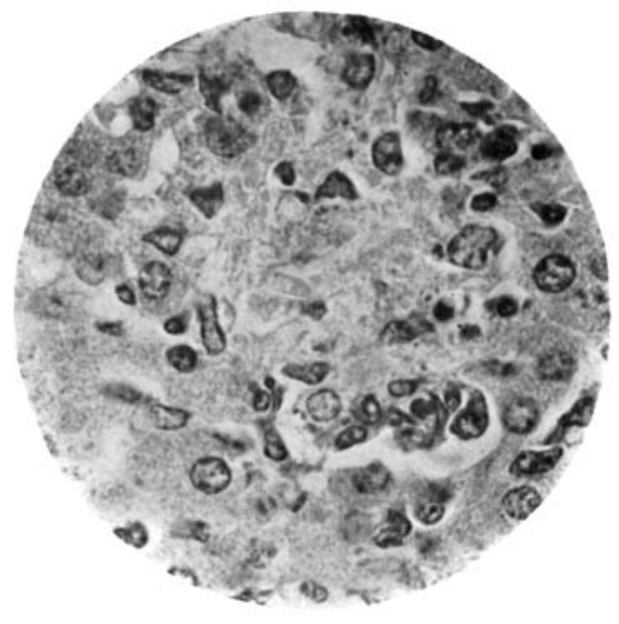

Fia. 6.

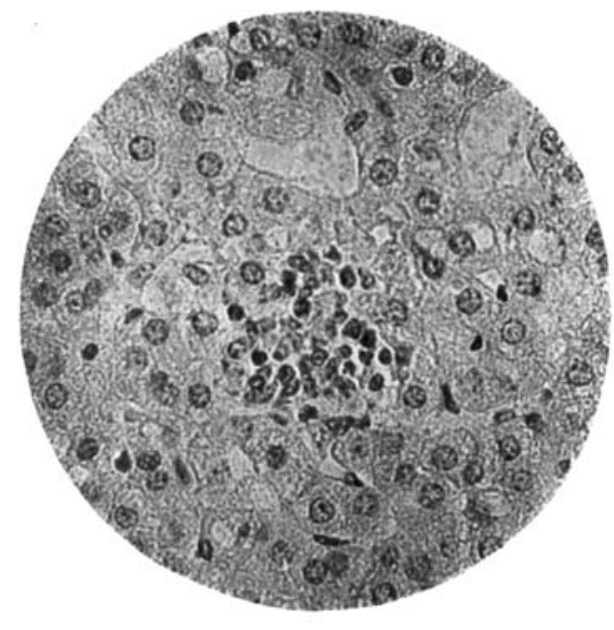

Fia. 8. 